ARTICLE

Received 5 Feb 2015 | Accepted 29 Jun 2015 | Published 25 Aug 2015

DOI: $10.1038 /$ ncomms 8966

OPEN

\title{
Metal-induced malformations in early Palaeozoic plankton are harbingers of mass extinction
}

\author{
Thijs R.A. Vandenbroucke ${ }^{1,2, \star}$, Poul Emsbo ${ }^{3, \star}$, Axel Munnecke ${ }^{4}$, Nicolas Nuns $^{5}$, Ludovic Duponchel ${ }^{6}$, \\ Kevin Lepot ${ }^{7}$, Melesio Quijada ${ }^{7}$, Florentin Paris ${ }^{8}$, Thomas Servais ${ }^{1} \&$ Wolfgang Kiessling ${ }^{4,9}$
}

Glacial episodes have been linked to Ordovician-Silurian extinction events, but cooling itself may not be solely responsible for these extinctions. Teratological (malformed) assemblages of fossil plankton that correlate precisely with the extinction events can help identify alternate drivers of extinction. Here we show that metal poisoning may have caused these aberrant morphologies during a late Silurian (Pridoli) event. Malformations coincide with a dramatic increase of metals ( $\mathrm{Fe}, \mathrm{Mo}, \mathrm{Pb}, \mathrm{Mn}$ and $\mathrm{As}$ ) in the fossils and their host rocks. Metallic toxins are known to cause a teratological response in modern organisms, which is now routinely used as a proxy to assess oceanic metal contamination. Similarly, our study identifies metal-induced teratology as a deep-time, palaeobiological monitor of palaeo-ocean chemistry. The redox-sensitive character of enriched metals supports emerging 'oceanic anoxic event' models. Our data suggest that spreading anoxia and redox cycling of harmful metals was a contributing kill mechanism during these devastating Ordovician-Silurian palaeobiological events.

\footnotetext{
${ }^{1}$ Unité Evolution, Ecologie et Paléontologie-UMR 8198, CNRS/Université de Lille-Sciences et Technologies, Avenue Paul Langevin, bâtiment SN5, 59655 Villeneuve d'Ascq, France. ${ }^{2}$ Department of Geology and Soil Sciences (WE13), Ghent University, Krijgslaan 281/S8, 9000 Ghent, Belgium. ${ }^{3}$ U.S. Geological Survey, Central Mineral and Environmental Resources Science Center, Denver Federal Center, Denver, Colorado 80225, USA. ${ }^{4}$ Universität Erlangen-Nürnberg, GeoZentrum Nordbayern, Fachgruppe Paläoumwelt, Loewenichstrasse 28, D-91054 Erlangen, Germany. ${ }^{5}$ IMMCL Chevreul, Université de Lille-Sciences et Technologies, Cité Scientifique, bâtiment C3, 59655 Villeneuve d'Ascq, France. ${ }^{6}$ LASIR-UMR 8516, CNRS/Université de Lille-Sciences et Technologies, Cité Scientifique, bâtiment C5, 59655 Villeneuve d'Ascq, France. ${ }^{7}$ Laboratoire d'Océanologie et de Géosciences-UMR 8187, CNRS/Université de LilleSciences et Technologies, Avenue Paul Langevin, bâtiment SN5, 59655 Villeneuve d'Ascq, France. ${ }^{8}$ Géosciences Rennes-UMR 6118, CNRS/Université de Rennes 1, Campus de Beaulieu, 35042 Rennes, France. ${ }^{9}$ Museum für Naturkunde, Leibniz Institute for Research on Evolution and Biodiversity at the Humboldt University Berlin, 10115 Berlin, Germany. * These authors contributed equally to this work. Correspondence and requests for materials should be addressed to T.R.A.V. (email: Thijs.vandenbroucke@UGent.be).
} 


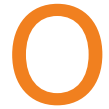

rdovician-Silurian rocks record several dramatic, positive stable isotope excursions indicative of major disturbances of the oceanic carbon, oxygen and sulfur cycles ${ }^{1,2}$. The environmental changes linked to these disturbances had a devastating effect on marine life. One of these events (the end-Ordovician Hirnantian event) features among the 'Big Five' Phanerozoic mass-extinction episodes ${ }^{3}$. Several other Ordovician-Silurian events are also marked by substantially elevated extinction rates among certain groups of marine taxa ${ }^{4-6}$, including the decimation of up to $95 \%$ of graptolite species during the Mulde event ${ }^{5}$ and $80 \%$ of conodonts during the Ireviken event $^{4}$, along with losses in trilobites, brachiopods, corals, acritarchs, graptolites and chitinozoans. The Pridoli event that is studied here mainly affected corals, chitinozoans, graptolites and conodonts. Current causative models often revolve around the direct effects of changing palaeoclimate, such as cooling temperatures and habitat reduction, but do not fully integrate observed palaeontological, geological and geochemical shifts during these events ${ }^{7,8}$. Rooted in earlier models, emerging geochemical and sedimentological evidence suggests that some of these disturbances are more directly linked to global oceanic anoxic events (OAEs) instead ${ }^{10-12}$. With the exception of some obvious links such as the drawdown of marine oxygen levels, however, the full set of interactions between OAEs originating in deep oceanic waters and mechanisms leading to extinctions across groups and palaeo-ecological niches on the continental shelves is still poorly understood. Elevated abundances of malformed (teratological) fossil microplankton (acritarchs and chitinozoans) mark the onset of the global, positive $\delta^{13} \mathrm{C}_{\text {carb }}$ excursions $^{13}$, and coincide with the initiation of extinction ${ }^{14}$.

Whereas modern instances of teratology in aquatic micro- and macroorganisms have been linked to a variety of environmental stressors, the teratological effects of heavy metal pollution have been well established in the natural environment and laboratory

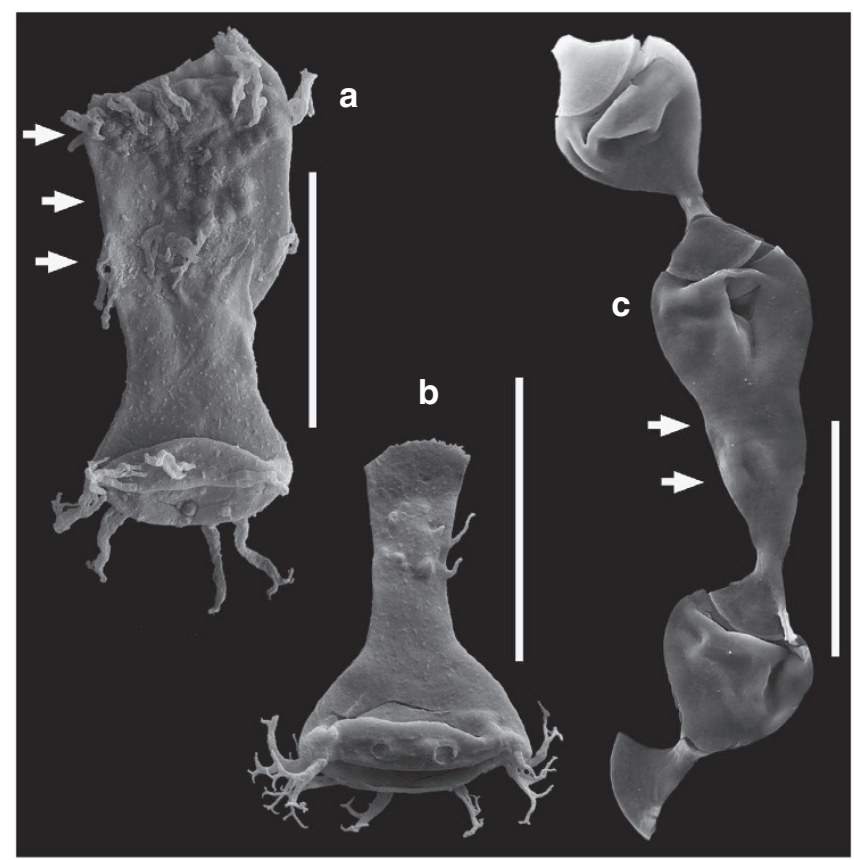

Figure 1 | Teratological and normal chitinozoans from core 14 in the A1-61 well. (a) Teratological specimen of Ancyrochitina (sample 2,127.5 m). (b) Morphologically normal specimen of Ancyrochitina for comparison (sample 2,127.5 m). (c) Chain of three specimens of Margachitina, with an abnormal specimen in between two normal ones (sample 2,126.75 m). Scale bars, $100 \mu \mathrm{m}$. Arrows indicate abnormal growth features. experiments. Malformation in diatoms $s^{15,16}$, foraminifera ${ }^{17,18}$ flagellates ${ }^{19}$, echinoderms ${ }^{20}$, arthropods ${ }^{21}$ and fish $^{22,23}$ is now routinely used as a powerful forensic tool to identify contamination of fresh, brackish and marine waters. Biomonitoring of ecotoxicity using eggs (for example, of copepods or cladocerans) typically focuses on hatching success and viability of embryos and neonates ${ }^{24}$. Nevertheless, malformation has also been observed in copepod egg ${ }^{25}$ and chrysophyte algae cyst morphologies ${ }^{26}$, respectively, triggered by diatom-enriched diets of the parent copepods, and Mn-Cd metal pollution of the environment of the algae that originally produced the cysts. In terms of affected functional morphology, these modern case studies involving cysts and eggs are strikingly similar to those of chitinozoans and acritarchs in the early Palaeozoic record. In the modern, such studies of resting stages are uncommon because the producing organism can be studied directly. As soft-bodied parent organisms are usually not preserved in the fossil record, we are obliged to use readily preserved egg cases or cysts to reconstruct the original oceanic conditions.

Here, in analogy with the modern, we test whether palaeo pollution of the marine environment by toxic metals might have also caused the Silurian teratologies. We explore the geochemical signal of chitinozoan assemblages at one of the events with elevated abundances of malformed specimens near the end of the Silurian. Chitinozoans are organic-walled microfossils (palynomorphs), 100-500 $\mu \mathrm{m}$ long, which probably represent fossil egg cases of marine zooplankton that lived in the shallow mixed layer of the Ordovician-Silurian oceans ${ }^{27}$. We show that their teratology coincides with metal enrichment in host rocks and fossils.

\section{Results}

Chitinozoan teratology. Malformed acritarchs (cysts of marine phytoplankton $^{28}$ ) can be abundant during these ancient events. For instance, there are up to $20 \%$ of teratological specimens in the affected assemblages from the Hirnantian of Anticosti Island ${ }^{13,14}$. The documented proportions of malformed chitinozoans are much lower: assemblages with c. $0.1 \%$ of affected specimens are considered anomalous, markedly above estimated background values of $0.01-0.001 \%$ (ref. 29). Nevertheless, we focused on the analysis of chitinozoans (Fig. 1) because they are an order of magnitude larger in size than acritarchs and thus easier to manipulate and analyse. We apply a new combination of techniques to measure the metal content of individual palynomorph specimens from teratological assemblages using time-of-flight secondary ion mass spectrometry (ToF-SIMS) and the bulk rock that hosts them, using laser ablation-inductively coupled plasma-mass spectrometry (LA-ICP-MS; see Methods). We selected a mid-Pridoli (late Silurian) event for which a teratology anomaly in the palynomorphs has been well established ${ }^{29,30}$. The samples are from a well in the Libyan desert that cuts through the Mesozoic and Palaeozoic sequence of the Gondwanan platform (Fig. 2). The studied interval consists of a sequence of regularly alternating siltstones and shales, with thin oolithic-ferruginous beds near the top of the section. Samples were collected from a series of cored intervals (Fig. 2) that yield abundant, exquisitely preserved palynomorphs. In core 14, teratological assemblages of chitinozoans ${ }^{29}$ and acritarchs ${ }^{30}$ of mid-Pridoli age (Margachitina elegans biozone ${ }^{31}$ ) have been previously described, respectively, between $2,127.5$ and $2,125 \mathrm{~m}$, and 2,129.6 and $2,126.4 \mathrm{~m}$. This narrow cored interval yielded multiple samples and assemblages where the frequency of teratological chitinozoan specimens was one or two orders of magnitude above background estimates ${ }^{29}$. Published counts 


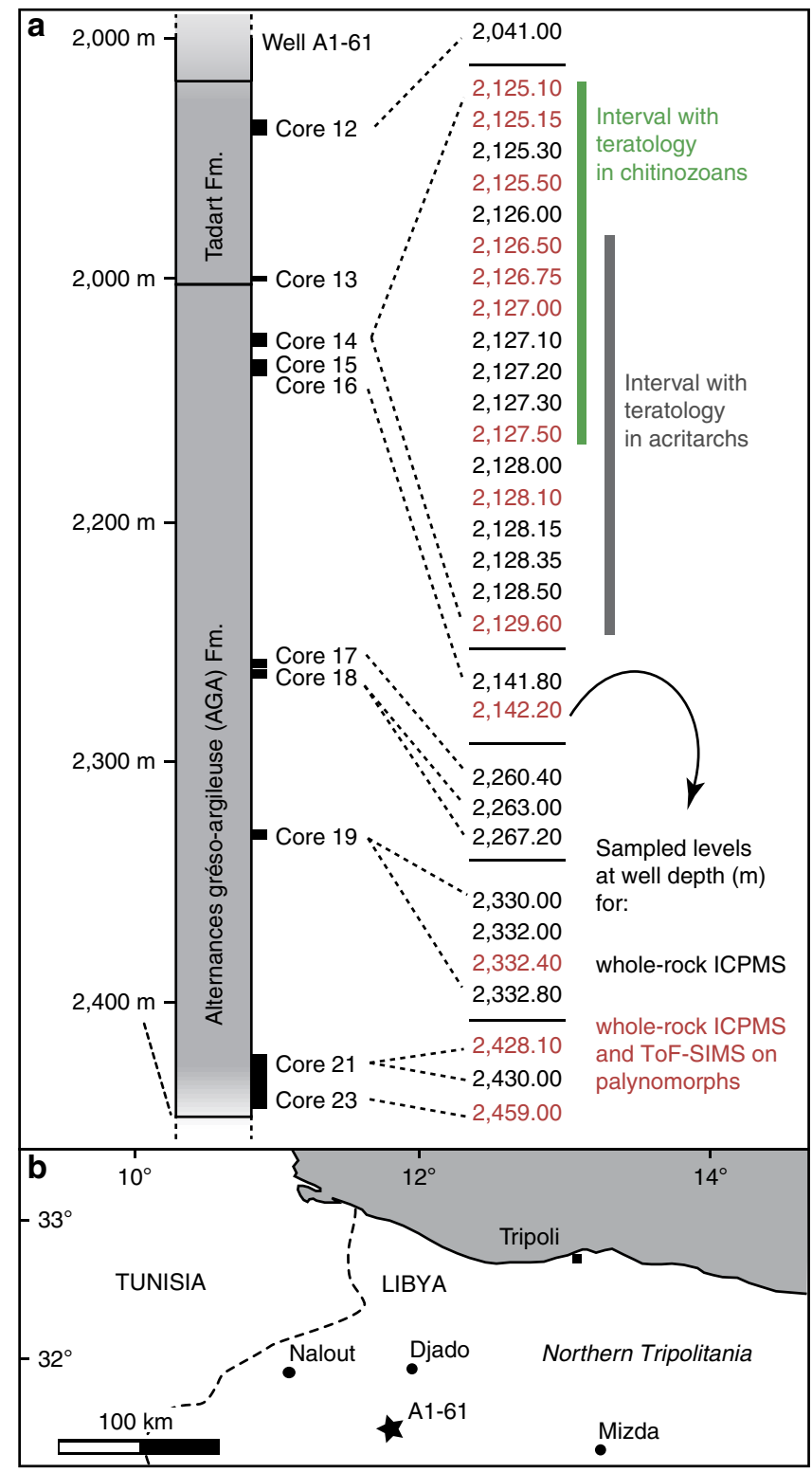

Figure 2 | The studied well section. (a) A1-61 well section showing the cored intervals and analysed samples. The teratological interval for chitinozoans in core 14 has been extended downwards by $0.5 \mathrm{~m}$ compared with published data ${ }^{29}$ as we found additional malformed specimens at 2,127.5-m depth. The documented acritarch teratology from core 19 is from samples $(2,333.8-2,333.7 \mathrm{~m})$ that are outside of the series available to us for analyses ${ }^{30}$. (b) Map of well locality in Libya.

exceed $0.1 \%$ of malformed specimens and even up to $1.3 \%$ of affected ancyrochitinids ${ }^{29}$. Many additional specimens have been recovered from the same levels in the current study (Supplementary Dataset 1). Any taphonomic causes for the teratological morphologies have been excluded beyond reasonable doubt ${ }^{29,30}$. The morphological deformities consist of significant defects, including wild growth of tissue, and the uncontrolled twinning of specimens (Fig. 1a), which are clearly outside of the range of intraspecific variability. These cannot be confused with regularly occurring ecophenotypes of the same species, which display a continuous spectrum of much more subtle morphological variability linked to the changes in ecology, as for instance documented in the length of dinocyst spines that varies with salinity ${ }^{32}$.
Geochemistry. The metal content, particularly $\mathrm{Fe}, \mathrm{Cu}, \mathrm{As}, \mathrm{Al}, \mathrm{Pb}$, $\mathrm{Ba}$, Mo and $\mathrm{Mn}$, of individual chitinozoans and/or bulk-rock samples increases markedly in the teratological interval (Fig. 3a). $\mathrm{Fe}$, As and $\mathrm{Mn}$ concentrations in bulk-rock samples increase by an order of magnitude, for example, from c. 50,000 to c. 400,000 p.p.m. Fe, on cue with the appearance of ooliticferruginous beds in the stratigraphic section (Fig. 3b). Principal component analysis on the ToF-SIMS data clearly separates the lower samples from those of the teratological interval; this is due to elevated metal content of the chitinozoan specimens in assemblages with malformation, notably of $\mathrm{Fe}, \mathrm{Al}$, $\mathrm{Mo}$ and $\mathrm{Ba}$ (Fig. 4a). While the metal enrichment in the teratology horizon is evident both in individual chitinozoans and in bulk-rock chemistry, abundances of certain elements in bulk-rock samples are decoupled from those in the palynomorphs: for example, bulk-rock Ba contents are relatively constant, yet the chitinozoan $\mathrm{Ba}$ shows a significant increase in the teratological zone (Fig. 3a). In addition, at decimetre scale and notably within the horizon with malformations, specimen and bulk-rock chemistry is statistically decoupled for all elements as evidenced by time-series cross-correlation tests (Figs $3 \mathrm{~b}$ and $4 \mathrm{~b}$ ). This decoupling demonstrates that the chemistry of chitinozoans is not a mere imprint of rock composition but may preserve the original chemistry of the organisms and thus reflect metal abundances in their aquatic environment. Relying exclusively on the chemical signature of the chitinozoans to represent original ocean chemistry may be subject to debate. However, the coincidence between malformations, a primary biological feature developed in vivo, and the increased metal contents in the organisms and sediments, in combination, is best explained by an increase in dissolved metals in the water column during the life of the organism and deposition of the sediments. We conclude that metal pollution, that is, the uptake of those metals during life and/or harmful conditions that developed in tandem with a rising metal content of the seawater, is the most likely explanation for the increase of teratology observed in these fossils.

\section{Discussion}

The mid-Pridoli teratology event correlates with faunal turnover $^{33}$ and a positive $\delta^{13} \mathrm{C}$ excursion ${ }^{34}$ (Fig. 5). Early Palaeozoic bioevents were generally accompanied by large, positive $\delta^{13} \mathrm{C}_{\text {carb }}$ excursions. Consensus is converging that such signatures may reflect the burial and sequestration of isotopically light carbon on the deep seafloor during developing OAEs ${ }^{35}$. It is also well established that transitions to anoxic conditions in modern marine environments increase markedly the solubility of some metals in seawater ${ }^{36}$. Most significantly, suboxic conditions lead to the reductive dissolution of $\mathrm{Fe}-\mathrm{Mn}$ oxyhydroxides, increasing the concentration of $\mathrm{Fe}$ and $\mathrm{Mn}$ in modern seawater by orders of magnitude. The concentration of some trace elements such as As, Mo and rare earth elements are directly controlled by absorptive scavenging and co-deposition with these oxyhydroxides; and as a consequence of reductive dissolution of oxyhydroxides, increase significantly in concentration in the seawater ${ }^{37-39}$. Moreover, transitions from oxic to anoxic oceanic conditions can trigger massive shifts in the cycling of Fe-Mn oxyhydroxides sequestered in sub-seafloor sediments, thereby triggering a benthic flux of $\mathrm{Fe}$, $\mathrm{Mn}$ and associated trace elements from the sediments into the anoxic seawater ${ }^{37,38,40}$. Other elements, such as $\mathrm{Ba}$, are governed by linked processes such as the reduction of sulfate in anoxic sediments $^{41}$. We posit that the observed metal enrichments and teratology during this Pridoli event reflects the encroachment of metal-enriched, oxygen-depleted oceanic waters into the oxic environments of the continental shelves. As this redox front moved into shallow water, the toxic mix of elements was introduced into the shelf ecosystems teeming with Silurian life. 
a

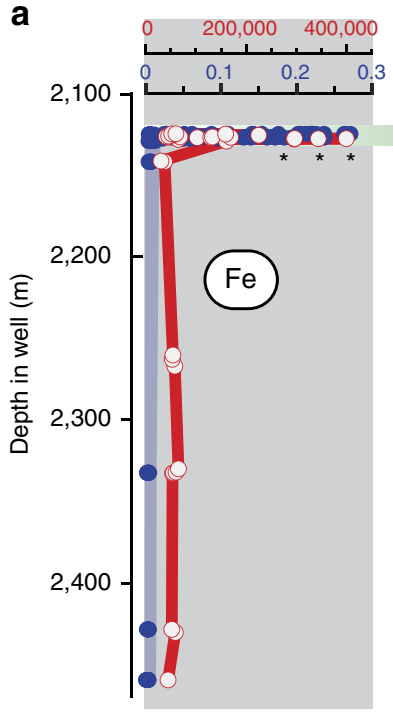

b

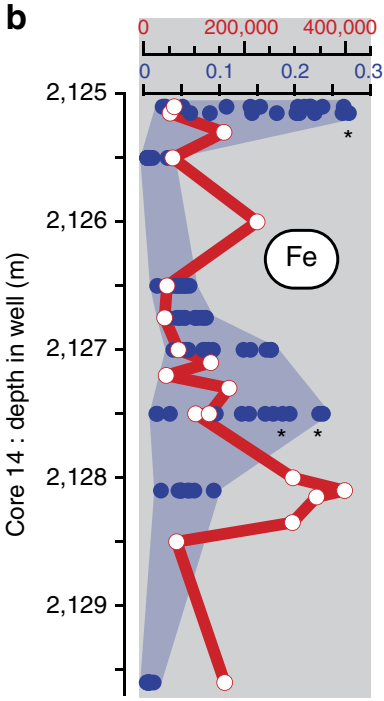

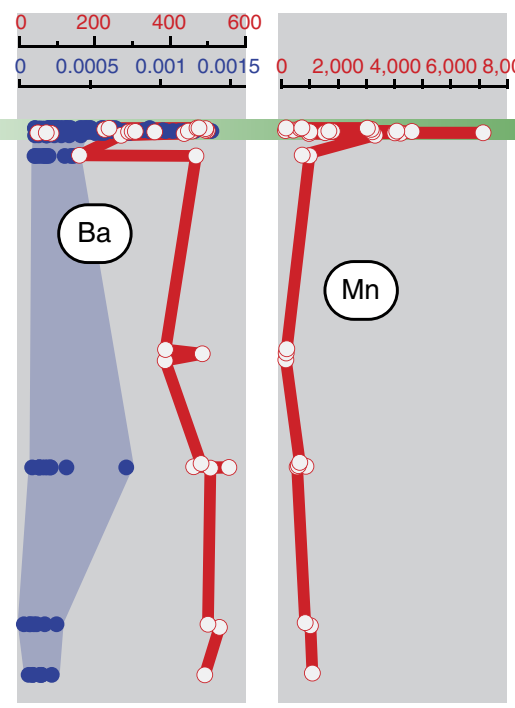

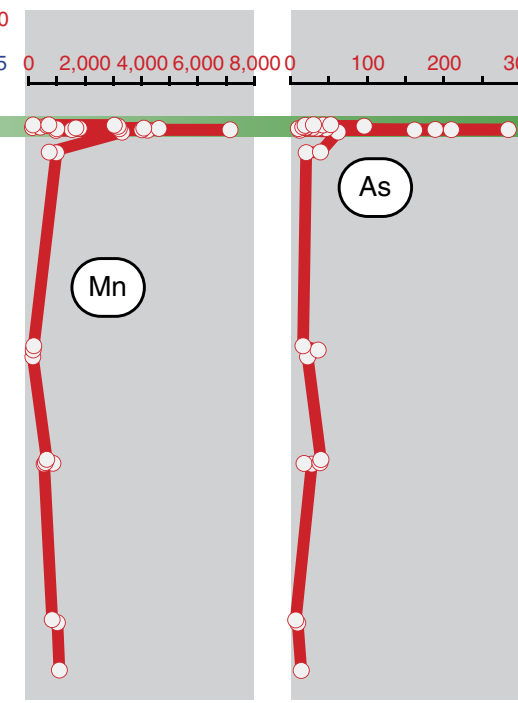

p.p.m. (LA-ICP-MS)

Normalized counts

(ToF-SIMS)

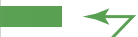

Interval with chitinozoan

teratology in core 14

(cf. zoom below, panel b)
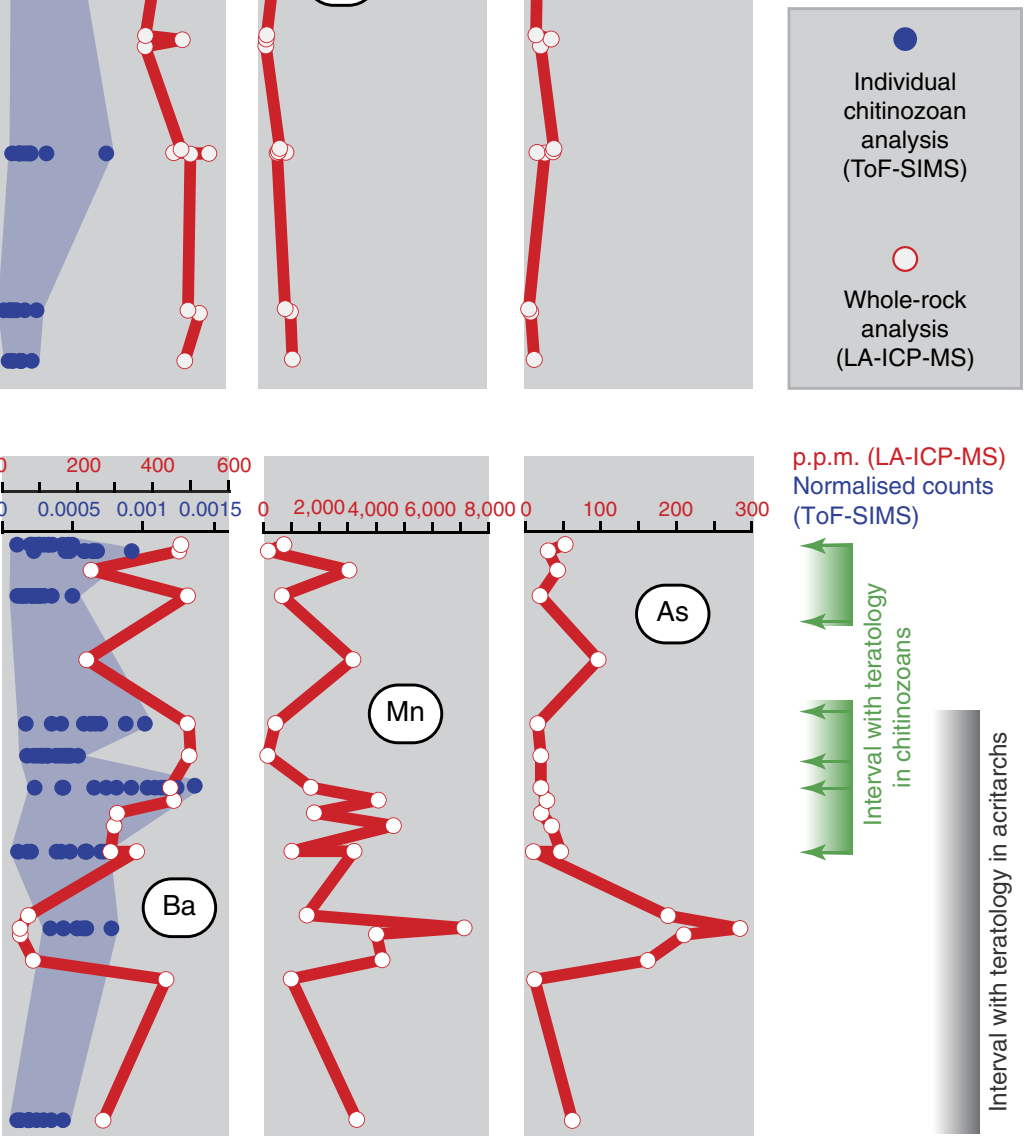

p.p.m. (LA-ICP-MS

Normalised counts (ToF-SIMS)

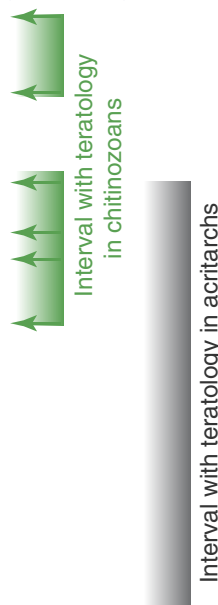

Figure 3 | Geochemical signal of selected elements through well A1-61. (a) Whole-rock Fe, $\mathrm{Mn}$ and As data display clear peaks in the chitinozoan teratological interval, markedly above background values lower in the well (LA-ICP-MS, in p.p.m.). Analyses on individual chitinozoans exhibit peaks in certain elements ( $\mathrm{Fe}$ and $\mathrm{Ba}$ ) in the teratological interval (ToF-SIMS, semi-quantitative). Asterisks $\left(^{\star}\right)$ indicate saturation at detector (that is, underestimated values). Elements (for example, As and $\mathrm{Mn}$ ) subject to spectral interference and/or below detection limit of the ToF-SIMS analyses cannot be directly compared with the bulk rock. (b) Geochemical signals in the event horizon. Concentrations of whole-rock Fe, Mn, and As data, as well as Fe and $\mathrm{Ba}$ in individual chitinozoans are significantly above background. Green arrows mark samples with teratological chitinozoans.

Consequently, the metals were re-oxidized and precipitated, each at their own pace (Supplementary Dataset 1), at the redox interface between the anoxic water mass and local oxic surface waters. This scenario accounts for the accumulation of redoxsensitive metals in both the sediments and fossils and explains the teratology of organisms during the Pridoli event. This interpretation is supported by similar enrichments of redoxsensitive metals through the early Wenlock Ireviken event ${ }^{12}$, by the enrichment of rare earth elements in widespread phosphorites across Laurentia ${ }^{42}$, and by the concurrence of ironstones with Silurian C-isotope excursions in the Appalachian Basin (USA). The US sections display consistent patterns of red, green and black marine sedimentary rocks, indicative of increasingly anoxic conditions ${ }^{10}$. In this model, the harmful effects of spreading dead zones $^{43}$, decreasing oxygen and increasing metal concentrations are intricately entangled. For instance, a study ${ }^{44}$ of the seasonally anoxic Chesapeake Bay links the sudden occurrence of malformed foraminifer Ammonia to the onset of anoxic conditions in the 1970s. However, it is also known that these seasonal anoxic conditions triggered the prompt release of redoxsensitive metals from the sediments into the water column ${ }^{40}$. In our Silurian data, metal-enriched malformed assemblages occur at the onset of the carbon isotope excursions, while hypoxia was starting to spread (and before it peaks later, indicated by the deposition of black shales ${ }^{10}$ ). This suggests that a direct toxic effect of metal enrichment contributed to the most plausible mechanism for the deformities in the organisms. Other environmental stressors that are known to cause malformation in the modern include changes in light intensity, ultraviolet radiation, predation, salinity and $\mathrm{pH}$, and could have coincided with spreading anoxic waters, but there is no empirical evidence for such changes in the event interval.

The metal composition of marine sedimentary rocks is a fundamental parameter used to interpret the chemical evolution 
a

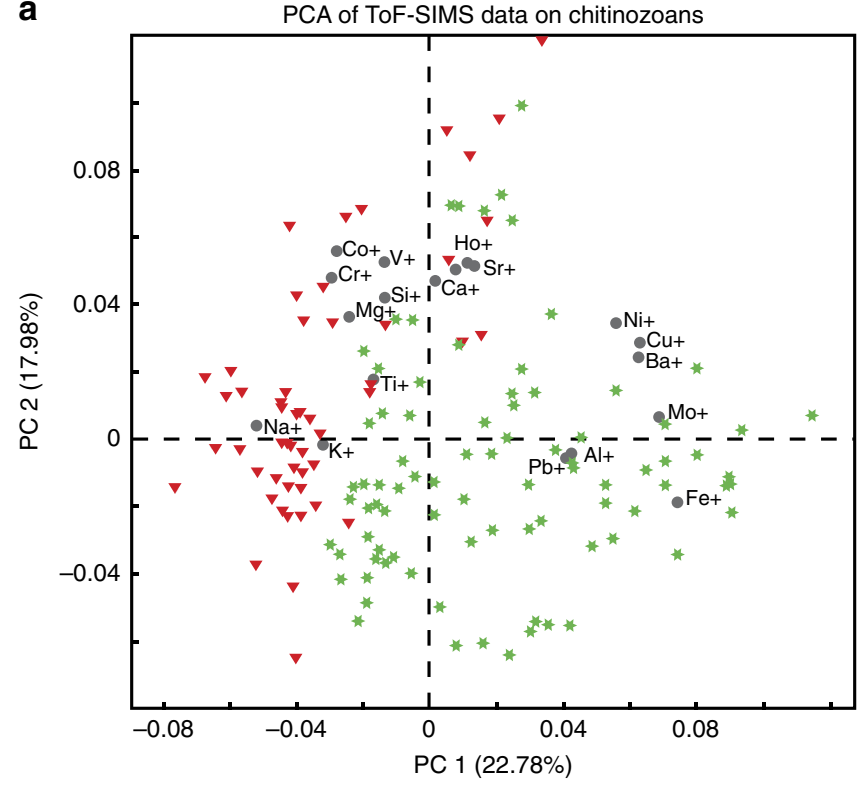

* Chitinozoan in an assemblage with increased teratology

$\checkmark$ Chitinozoan in an assemblage without increased teratology

b

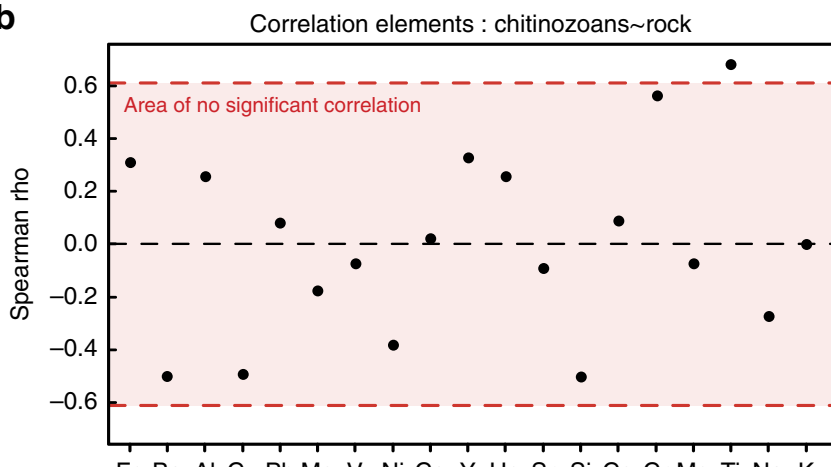

Figure 4 | Statistical analyses of the geochemical data. (a) Principal component analysis (PCA) of ToF-SIMS data of chitinozoans indicates a clear separation of samples from within (green stars) and outside (red triangles) of their teratological interval, based on their geochemistry and mainly driven by elements such as $\mathrm{Fe}, \mathrm{Al}, \mathrm{Cu}, \mathrm{Ba}, \mathrm{Mo}$ and $\mathrm{Pb}$. The PCA was carried out using the Eigenvector PLS toolbox (Eigenvector Research Inc., Wenatchee, WA, USA) in the MATLAB environment version 8.0 (The MathWorks, Natick, MA, USA). Data on 19 elements of 141 ToF-SIMS spectra (spread over 13 stratigraphical levels) were pre-scaled using autoscaling ${ }^{47}$ (spectral variables are scaled to a zero mean and unit variance) as some of the spectral peaks of interest are relatively small. Three samples were extremely enriched in $\mathrm{Fe}$ and $\mathrm{Al}$ and these outliers were eliminated. (b) Correlation values between element concentrations in chitinozoans and whole-rock data. Measurements were averaged across $20-\mathrm{cm}$ intervals of core and scaled to a mean of zero and unit variance before non-parametric correlation tests. Red lines indicate approximate correlation coefficients for a significant cross-correlation ( $P=0.05$ ). Only $\mathrm{Ti}$ is significantly correlated between chitinozoans and rock samples. PC, principal component.

of the Earth's atmosphere and hydrosphere. Yet, generally, uncertainty remains regarding the primary metal abundances in seawater, pathways of metal accumulation and post-depositional modification of metal abundances in sedimentary rocks. As demonstrated in modern marine environments, our results suggest that metal-induced teratology of fossil plankton may serve as an independent proxy for monitoring changes in the metal concentrations of the shallow palaeo-ocean. This new proxy

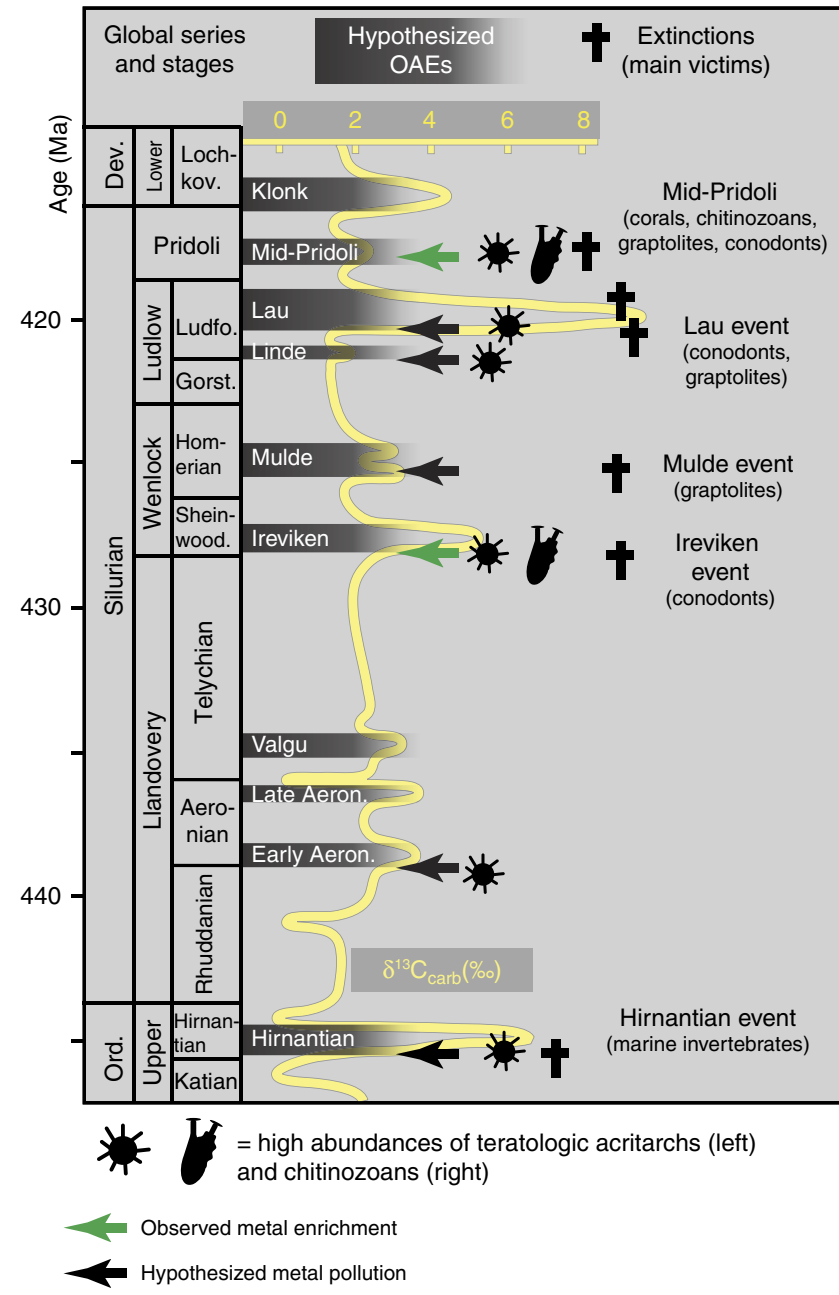

Figure 5 | Distribution of potential OAEs in the uppermost Ordovician and Silurian. The position of the suggested OAEs is based on $\delta^{13} \mathrm{C}$ stratigraphy ${ }^{34}$. Key victims of the extinction events and the events with increased occurrences of teratology are highlighted ${ }^{13}$. Metal toxicity is observed in the Pridoli (this study) and implied during the Ireviken event, where metal enrichments in carbonates and phosphates in SE Sweden indicate anoxia ${ }^{12}$. For a full list of affected fauna see Kaljo et al. ${ }^{33}$ and Calner ${ }^{6}$. Ord., Ordovician; Dev., Devonian.

enables us here to reduce these uncertainties and supports the interpretation that the sedimentary chemistry reflects changing oceanic metal compositions during OAEs. As such, this proxy has the potential to help unravel the complexities inherent to sedimentary geochemistry, and may be a tool to evaluate other instances of marine metal variation through the geological record.

The co-occurrence between mid-Pridoli teratology and the onset of extinction suggests that metal contamination may have played a direct role in the biological crisis at large. More generally, the recurring temporal match between Ordovician-Silurian teratology events and extinction events ${ }^{13}$ raises the prospect that toxic metal contamination may be a previously unrecognized contributing agent to many, if not all, of these bioevents (Fig. 5). In sections where such data exist, teratological phytoplankton precede or co-occur with the earliest phases of these major extinction events. Taken at face value, for example, Hirnantian acritarch malformation in the Lousy Cove Member (member 6) of the Ellis Bay Formation coincides with the onset of the 'phytoplankton crisis' on Anticosti Island (Canada) but precedes the major macrofauna extinctions in the overlying Laframboise 
Member (member 7) (refs 14,45). On Gotland (Sweden), increased acritarch malformation occurs around a series of marker beds ${ }^{46}$, identifying an interval that starts below the strongest extinctions of conodonts during the early Ireviken event ${ }^{4}$. Although the patterns and exact relative timing of teratology and extinction require confirmation, the available data suggest that malformed palynomorphs could be the proverbial 'canaries in the coal mines', that is, the first indicators of Palaeozoic extinctions.

Metal toxicity, and its fossilized in vivo expressions, could provide the 'missing link' between extinction of faunas on the shelf, and widespread ocean anoxia. As part of a series of complex systemic interactions accompanying these shifts in ocean conditions, the redox cycling of metals may identify the early phase of the kill mechanisms that culminated in these catastrophic events. Although OAEs typically entail rapid climatic change, our data suggest that the proposed mechanisms of these early Palaeozoic mass extinctions were previously too simply linked to global cooling, invoking thermal stress and habitat reduction. Ultimately, metal-induced teratology might become a new forensic tool to identify original oceanic geochemical signatures and may help unravel the biologic and geochemical systematics that define these extraordinary periods of Earth history.

\section{Methods}

Material. Samples were studied from the 3,176 m A1-61 borehole in Ral-el-Dorah in Libya that cuts through the Mesozoic, Devonian, Silurian and into the Upper Ordovician sequence. The samples were collected from infrequently cored Silurian intervals. The original biostratigraphic purpose of the well explains why not every iron oolite bed in core 14 was sampled systematically, as oolites do not normally yield age-diagnostic microfossils (Fig. 2). Our samples 2,127 and 2,125.1 are direct subsamples from those of Jaglin and Paris ${ }^{29}$. Note that the teratological interval for chitinozoans in core 14 has been extended downwards by $0.5 \mathrm{~m}$ (Fig. 2) compared with published range ${ }^{29}$ as we found additional malformed specimens at $2,127.5 \mathrm{~m}$ (Supplementary Dataset 1).

Palynology. Thirteen samples from A1-61 were dissolved for palynology. The core chips were broken into $0.5-\mathrm{cm}$ pieces and decarbonated using $34 \% \mathrm{HCl}$. They were then agitated with c. $200 \mathrm{ml} 48 \% \mathrm{HF}$ over c. $24 \mathrm{~h}$. Any newly formed fluor silicates were removed using a second $17 \% \mathrm{HCl}$ treatment, over $32 \mathrm{~h}$ and at $60^{\circ} \mathrm{C}$. Samples were neutralized and filtered at $51 \mu \mathrm{m}$. Individual palynomorphs were handpicked from the organic residue $(>51 \mu \mathrm{m})$ using a stereomicroscope at $\times 50-150$ magnification, and transferred onto glass slides with $\mathrm{Cu}$-tape and microscope grids, which were then used in ToF-SIMS analyses. Scanning electron microscope positioning of specimens versus reference grid was used to identify the specimens in the ToF-SIMS.

Time-of-flight secondary ion mass spectrometry. Individual microfossils from 13 samples from A1-61 were analysed using ToF-SIMS. ToF-SIMS spectra measurements were carried out using a TOF.SIMS 5 instrument (ION-TOF $\mathrm{GmbH}$, Germany). This instrument is equipped with a Bi liquid metal ion gun. Pulsed $\mathrm{Bi}_{3}{ }^{+}$primary ions have been predominantly used for analysis $(25 \mathrm{keV}$, $0.3 \mathrm{pA}$ ). Analyses were performed semi-quantitatively using two settings: 'mapping mode' ( $500 \times 500-\mu \mathrm{m}^{2}$ grids, and the acquired images were $512 \times 512$ pixels, which has the advantage of simultaneously analysing multiple specimens) and 'focused beam mode' (focussing the Bi-pulsed beam on a $5 \times 5-\mu \mathrm{m}^{2}$ grid and in doing so removing surface layers from specimens). Both 'mapping' and 'focused beam' acquisitions were performed in high-current bunched mode. The primary $\mathrm{Bi}_{3}{ }^{+}$ ion current measured in the Faraday cup was $0.4 \mathrm{pA}$. In the mapping-mode experimental conditions, we obtained a lateral resolution of c. $1 \mu \mathrm{m}$. Mass resolution calculated at $m / z=56$ for $\mathrm{Fe}^{+}$was $>4,000$. The primary ion dose density (PIDD, calculated after 10 shots per pixel) was $3 \times 10^{11}$ ions per $\mathrm{cm}^{2}$ indicative of static analytical conditions. In the focused beam mode, the mass resolution calculated at $m / z=56$ for $\mathrm{Fe}^{+}$remained $>4,000$. The primary ion dose density was $2 \times 10^{15}$ ions per $\mathrm{cm}^{2}$ (non-static). The focused beam mode allows for a substantial reduction of modern contaminants (for example, PDMS, see Supplementary Fig. 1). The data from the 170 focused beam analyses (including 141 on chitinozoans) are those presented in the main paper (Supplementary Datasets 1 and 2). Measurements were accumulated over 133-200 s. The mappingmode data are deposited as Supplementary Datasets 1 and 2, and mirror the trends of the focused beam-mode data. These ToF-SIMS maps also illustrate a uniform distribution of the key elements through the palynomorphs, excluding mineral origin (Supplementary Fig. 2).
Owing to the exploratory nature of study, the mapping-mode analyses used two different source modes, $\mathrm{Bi}^{+}$and $\mathrm{Bi}_{3}{ }^{+}$. These are clearly separated in the Supplementary Dataset 1. For the 'focused beam-mode' analyses, only the $\mathrm{Bi}_{3}{ }^{+}$ source was used (this is the data in Figs 3 and 4). The data from the ${ }^{\prime} \mathrm{Bi}_{3}{ }^{+}$mapping mode' clearly displays the same trend as for the 'focused beam' mode, that is, a clear increase in metals in the samples with teratological assemblages, compared with the other samples lower in the section (this is the bulk of the samples in Supplementary Dataset 1 ). For the ' $\mathrm{Bi}^{+}$mapping mode', this is somewhat less obvious (only three samples were analysed due to a markedly weaker signal), however, increases are observed for elements such as $\mathrm{Fe}, \mathrm{Al}$ and $\mathrm{Mo}$, in the chitinozoans of the two teratological samples analysed in $\mathrm{Bi}^{+}$mode.

Sixty-six ion peaks were originally selected in the spectra. Twenty-one remained after eliminating those with potential overlap (for example, between peaks of $\mathrm{Mn}$ and ${ }^{54} \mathrm{FeH}^{+}, \mathrm{Ga}^{+}$and $\mathrm{CHFe}^{+}$) and those below the background noise threshold We retained data for 19 ions (excluding $\mathrm{H}^{+}$and $\mathrm{C}^{+}$) from a total number of 534 specimens of chitinozoans, acritarchs, scolecodonts (jaws of polychaete annelids) spores and graptolite fragments (organic-walled macro-zooplankton) that were analysed in mapping mode (Supplementary Dataset 2); a further 170 analyses, focussing on chitinozoans, were conducted in focused beam mode.

Laser ablation-inductively coupled plasma-mass spectrometry. Major and trace element abundances for 32 bulk-sediment samples were determined by LA-ICP-MS at the USGS (Supplementary Dataset 3). Analyses are within 15\% of accepted values of USGS reference materials, duplicate analyses of selected samples by inductively coupled plasma-atomic emission spectrometry and inductively coupled plasma-mass spectrometry (ICP-AES-MS) sodium peroxide sinter (SGS Mineral Services, Toronto) and in-house ICP-AES-MS sinter methods. Replicate analyses were $<3 \%$ RSD

Cross-correlation. Chemical measurements of whole rocks and fossils were partitioned into $20-\mathrm{cm}$ regular-spaced intervals between $2,125.1$ and $2,459 \mathrm{~m}$. Chemical measurements of each element were averaged within each interval and empty intervals (no measurements) were omitted from each time series. Averaged values were standardized to unit variance and a mean of zero before performing cross-correlation tests. Reported correlation coefficients are without temporal lag and non-parametric (Spearman's Rho)

\section{References}

1. Munnecke, A., Calner, M., Harper, D. A. T. \& Servais, T. Ordovician and Silurian sea-water chemistry, sea level, and climate: a synopsis. Palaeogeogr. Palaeoclimatol. Palaeoecol. 296, 389-413 (2010).

2. Harper, D. A. T., Hammarlund, E. U. \& Rasmussen, C. M. O. End Ordovician extinctions: a coincidence of causes. Gondwana Res. 25, 1294-1307 (2014).

3. Sheehan, P. M. The Late Ordovician mass extinction. Annu. Rev. Earth Planet. Sci. 29, 331-364 (2001).

4. Munnecke, A., Samtleben, C. \& Bickert, T. The Ireviken Event in the lower Silurian of Gotland, Sweden-relation to similar Palaeozoic and Proterozoic events. Palaeogeogr. Palaeoclimatol. Palaeoecol. 195, 99-124 (2003).

5. Cramer, B. D. et al. U-Pb (zircon) age constraints on the timing and duration of Wenlock (Silurian) paleocommunity collapse and recovery during the "Big Crisis". Geol. Soc. Am. Bull. 124, 1841-1857 (2012).

6. Calner, M. in Mass Extinction (ed. Elewa, A. M. T.) 21-57 (Springer Book, 2008).

7. Ghienne, J. F. et al. A Cenozoic-style scenario for the end-Ordovician glaciation. Nat. Commun. 5, 4485 (2014).

8. Cramer, B. D. \& Saltzman, M. R. Early Silurian paired $\delta^{13} C_{\text {carb }}$ and $\delta^{13} C_{\text {org }}$ analyses from the Midcontinent of North America: implications for paleoceanography and paleoclimate. Palaeogeogr. Palaeoclimatol. Palaeoecol. 256, 195-203 (2007).

9. Bickert, T., Pätzold, J., Samtleben, C. \& Munnecke, A. Paleoenvironmental changes in the Silurian indicated by stable isotopes in brachiopod shells from Gotland, Sweden. Geochim. Cosmochim. Acta 61, 2717-2730 (1997).

10. McLaughlin, P. I., Emsbo, P. \& Brett, C. E. Beyond black shales: the sedimentary and stable isotope records of oceanic anoxic events in a dominantly oxic basin (Silurian; Appalachian Basin, USA). Palaeogeogr. Palaeoclimatol. Palaeoecol. 367-368, 153-177 (2012).

11. Hammarlund, E. U. et al. A sulfidic driver for the end-Ordovician mass extinction. Earth Planet. Sci. Lett. 331-332, 128-139 (2012).

12. Emsbo, P. et al. The Ireviken Event: a Silurian OAE. Geol. Soc. Am. 42, 561 (2010).

13. Munnecke, A., Delabroye, A., Servais, T., Vandenbroucke, T. R. A. \& Vecoli, M. Systematic occurrences of malformed (teratological) acritarchs in the run-up of early Palaeozoic $\delta^{13} \mathrm{C}$ isotope excursions. Palaeogeogr. Palaeoclimatol. Palaeoecol. 367-368, 137-146 (2012).

14. Delabroye, A., Munnecke, A., Servais, T., Vandenbroucke, T. R. A. \& Vecoli, M. Abnormal forms of acritarchs (phytoplankton) in the upper Hirnantian (Upper Ordovician) of Anticosti Island, Canada. Rev. Palaeobot. Palynol. 173, 46-56 (2012) 
15. Morin, S. et al. Long-term survey of heavy-metal pollution, biofilm contamination and diatom community structure in the Riou Mort watershed, South-West France. Environ. Pollut. 151, 532-542 (2008).

16. Falasco, E. et al. Morphological abnormalities of diatom silica walls in relation to heavy metal contamination and artificial growth conditions. Water South Africa 35, 595-606 (2009).

17. Elberling, B., Knudsen, K. L., Kristensen, P. H. \& Asmun, G. Applying foraminiferal stratigraphy as a biomarker for heavy metal contamination and mining impact in a fiord in West Greenland. Mar. Environ. Res. 55, 235-256 (2003).

18. Le Cadre, V. \& Debenay, J. P. Morphological and cytological responses of Ammonia (foraminifera) to copper contamination: Implication for the use of foraminifera as bioindicators of pollution. Environ. Pollut. 143, 304-317 (2006).

19. Boenigk, J., Wiedlroither, A. \& Pfandl, K. Heavy metal toxicity and bioavailability of dissolved nutrients to a bacterivorous flagellate are linked to suspended particle physical properties. Aquat. Toxicol. 71, 249-259 (2005).

20. Kobayashi, N. \& Okamura, H. Effects of heavy metals on sea urchin embryo development. 1. Tracing the cause by the effects. Chemosphere 55, 1403-1412 (2004).

21. Di Veroli, A. et al. Deformities of chironomid larvae and heavy metal pollution: from laboratory to field studies. Chemosphere 112, 9-17 (2014).

22. Bengtsson, B. E. Biological variables, especially skeletal deformities in fish, for monitoring marine pollution. Phil. Trans. R. Soc. Lond. B 286, 457-464 (1979).

23. Sfakianakis, D. G., Renieri, E., Kentouri, M. \& Tsatsakis, A. M. Effect of heavy metals on fish larvae deformities: a review. Environ. Res. 137, 246-255 (2015).

24. Navis, S., Waterkeyn, A., Voet, T., De Meester, L. \& Brendonck, L. Pesticide exposure impacts not only hatching of dormant eggs, but also hatchling survival and performance in the water flea Daphnia magna. Ecotoxicology 22, 803-814 (2013).

25. Poulet, S. A. et al. Collapse of Calanus chilensis reproduction in a marine environment with high diatom concentration. J. Exp. Mar. Biol. Ecol. 352, 187-199 (2007)

26. Chen, X., Mao, X., Cao, Y. \& Yang, X. Use of siliceous algae as biological monitors of heavy metal pollution in three lakes in a mining city, southeast China. Int. J. Oceanogr. Hydrobiol. 42, 233-242 (2013).

27. Vandenbroucke, T. R. A. et al. Epipelagic chitinozoan biotopes map a steep latitudinal temperature gradient for earliest Late Ordovician seas: implications for a cooling Late Ordovician climate. Palaeogeogr. Palaeoclimatol. Palaeoecol. 294, 202-219 (2010).

28. Servais, T., Stricanne, L., Montenari, M. \& Pross, J. Population dynamics of galeate acritarchs at the Camrian-Ordovician transition in Algerian Sahara. Palaeontology 47, 395-414 (2004).

29. Jaglin, J.-C. \& Paris, F. Exemples de tératologie chez les chitinozoaires du Pridoli de Libye et implications sur la signification biologique du groupe. Lethaia 25, 151-164 (1992).

30. Le Hérissé, A. Palaeoecology, biostratigraphy and palaeogeography of late Silurian to early Devonian acritarchs and prasinophycean phycomata in well A1-61, western Libya, North Africa. Rev. Palaeobot. Palynol. 118, 359-395 (2002).

31. Jaglin, J.-C. \& Paris, F. Biostratigraphy, biodiversity and palaeogeography of late Silurian chitinozoans from A1-61 borehole (north-western Libya). Rev. Palaeobot. Palynol. 118, 335-358 (2002).

32. Mertens, K. N. et al. Process length variation in cysts of a dinoflagellate, Lingulodinium machaerophorum, in surface sediments: investigating its potential as salinity proxy. Mar. Micropaleontol. 70, 54-69 (2009).

33. Kaljo, D. et al. in Global Events and Event Stratigraphy in the Phanerozoic (ed Walliser, O. H.) 174-224 (Springer, 1995).

34. Cramer, B. D. et al. Revised correlation of Silurian Provincial Series of North America with global and regional chronostratigraphic units and $\delta^{13} \mathrm{C}_{\text {carb }}$ chemostratigraphy. Lethaia 44, 185-202 (2011).

35. Jenkyns, H. C. Geochemistry of oceanic anoxic events. Geochem. Geophys. Geosyst. 11, Q03004 (2010).

36. Calvert, S. E. \& Pedersen, T. F. Geochemistry of recent oxic and anoxic marine sediments: implications for the geological record. Mar. Geol. 113, 67-88 (1993).

37. Elderfield, H. \& Greaves, M. The rare earth elements in seawater. Nature 296, 214-219 (1982)

38. Elderfield, H., Upstill-Goddard, R. \& Sholkovitz, E. R. The rare earth elements in rivers, estuaries, and coastal seas and their significance to the composition of ocean waters. Geochim. Cosmochim. Acta 54, 971-991 (1990).
39. Mitra, A., Elderfield, H. \& Greaves, M. Rare earth elements in submarine hydrothermal fluids and plumes from the Mid-Atlantic Ridge. Mar. Chem. 46, 217-235 (1994).

40. Sholkovitz, E. R., Shaw, T. J. \& Schneider, D. L. The geochemistry of rare earth elements in the seasonally anoxic water column and porewaters of Chesapeake Bay. Geochim. Cosmochim. Acta 56, 3389-3402 (1992).

41. Johnson, C. A., Emsbo, P., Poole, F. G. \& Rye, R. O. Sulfur- and oxygenisotopes in sediment-hosted stratiform barite deposits. Geochim. Cosmochim. Acta 73, 133-147 (2009).

42. Emsbo, P., McLaughlin, P. I., Breit, G. N., du Bray, E. A. \& Koenig, A. E. Rare earth elements in sedimentary phosphate deposits: solution to the global REE crisis? Gondwana Res. 27, 776-785 (2015).

43. Diaz, R. J. \& Rosenberg, R. Spreading dead zones and consequences for marine ecosystems. Science 321, 926-929 (2008).

44. Karlsen, A. W. et al. Historical trends in Chesapeake Bay dissolved oxygen based on benthic Foraminifera from sediment cores. Estuaries 23, 488-508 (2000).

45. Achab, A., Asselin, E., Desrochers, A., Riva, J. F. \& Farley, C. Chitinozoan biostratigraphy of a new Upper Ordovician stratigraphic framework for Anticosti Island, Canada. Geol. Soc. Am. Bull. 123, 186-205 (2011).

46. Le Hérissé, A. Acritarches et kystes d'algues Prasinophycées du Silurien de Gotland, Suède. Palaeontogr. Ital. 76, 57-302 (1989).

47. Gemperline, P. Practical Guide To Chemometrics 2nd edn (CRC Press, 2006).

\section{Acknowledgements}

T.R.A.V., M.Q. and K.L. acknowledge the financial support from the CNRS (INSU, action INTERRVIE), and the Regional Council of Nord-Pas de Calais (emergent projects action) in France. T.R.A.V. and T.S. acknowledge the financial support from the ANR through grant 12-BS06-0014 'SeqStrat-Ice'. N.N. acknowledges funding from the Chevreul institute (FR 2638), the European Regional Development Fund (FEDER), CNRS, the Regional Council of Nord-Pas de Calais and Ministère de l'Education Nationale de l'Enseignement Supérieur et de la Recherche for the ToF-SIMS spectrometer at the Pôle Régional d'Analyses de Surface. Laurence Debeauvais and Philippe Recourt (both CNRS, Univ. Lille) are thanked for the assistance with palynology lab protocols and scanning electron microscope imaging, respectively. Marco Vecoli (Saudi Aramco) is acknowledged for providing access to samples. This is a contribution to IGCP 591 'The early to middle Palaeozoic revolution'. Any use of trade, product, or firm names is for descriptive purposes only and does not imply endorsement by the U.S. Government.

\section{Author contributions}

T.R.A.V., P.E., A.M. and T.S. designed the project; T.R.A.V. performed palynological analyses; P.E. produced LA-ICP-MS data; N.N. and T.R.A.V. performed ToF-SIMS analyses; T.R.A.V., M.Q. and K.L. processed data; L.D. performed principal component analyses; W.K. performed cross-correlation analyses; F.P. provided samples; T.R.A.V., P.E., A.M. and W.K. wrote the paper.

\section{Additional information}

Supplementary Information accompanies this paper at http://www.nature.com/ naturecommunications

Competing financial interests: The authors declare no competing financial interests.

Reprints and permission information is available online at http://npg.nature.com/ reprintsandpermissions/

How to cite this article: Vandenbroucke, T. R. A. et al. Metal-induced malformations in early Palaeozoic plankton are harbingers of mass extinction. Nat. Commun. 6:7966 doi: $10.1038 /$ ncomms8966 (2015).

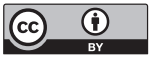

This work is licensed under a Creative Commons Attribution 4.0 International License. The images or other third party material in this article are included in the article's Creative Commons license, unless indicated otherwise in the credit line; if the material is not included under the Creative Commons license, users will need to obtain permission from the license holder to reproduce the material. To view a copy of this license, visit http://creativecommons.org/licenses/by/4.0/ 